\title{
Somatostatin receptors 2 and 5 are preferentially expressed in proliferating endothelium
}

\author{
RL Adams', IP Adams', SW Lindow', W Zhong' and SL Atkin ${ }^{*, 1}$ \\ 'Endocrinology Research Group, Division of Academic Medicine, University of Hull Postgraduate Medical School, Hull HU6 7RX, UK; ${ }^{2}$ Department of \\ Obstetrics and Gynecology, Hull Women and Children's Hospital, Hull HU3 2JZ, UK
}

Angiogenesis is characterised by activation, migration and proliferation of endothelial cells and is central to the pathology of cancer, cardiovascular disease and chronic inflammation. Somatostatin is an inhibitory polypeptide that acts through five receptors (sst I, 2, 3, $4,5)$. Sst has previously been reported in endothelium, but their role remains obscure. Here, we report the expression of sst in human umbilical vein endothelial cells (HUVECs) in vitro, during proliferation and quiescence. A protocol for culturing proliferating and quiescent HUVECs was established, and verified by analysing cell cycle distribution in propidium-iodide-stained samples using flow cytometry. Sst mRNA was then quantified in nine proliferating and quiescent HUVEC lines using quantitative reverse transcriptase-polymerase chain reaction. Sst 2 and 5 were preferentially expressed in proliferating HUVECs. All samples were negative for sst 4. Sst I and 3 expression and cell cycle progression were unrelated. Immunostaining for sst 2 and 5 showed positivity in proliferating but not quiescent cells, confirming sst 2 and 5 protein expression. Inhibition of proliferating cells with somatostatin analogues Octreotide and SOM230, which have sst 5 activity, was found (Octreotide $10^{-10}-10^{-6} \mathrm{M}$ : 48.5-70.2\% inhibition; SOM230 $10^{-9}-10^{-6} \mathrm{M}: 44.9-65.4 \%$ inhibition) in a dose-dependent manner, suggesting that sst 5 may have functional activity in proliferation. Dynamic changes in sst 2 and 5 expression during the cell cycle and the inhibition of proliferation with specific analogues suggest that these receptors may have a role in angiogenesis.

British Journal of Cancer (2005) 92, I493- |498. doi:I0.I038/sj.bjc.6602503 www.bjcancer.com

Published online 5 April 2005

(c) 2005 Cancer Research UK

Keywords: somatostatin receptors; endothelium; angiogenesis; proliferation; Octreotide; SOM230

Angiogenesis is a carefully regulated normal physiologic process, required for wound healing, reproduction and development (Griffioen and Molema, 2000). Vascular endothelial cells are normally quiescent cells, dividing every $2-5$ years (Woltering et al, 1997). However, endothelial cell stimulation by proangiogenic factors and cytokines from inflammatory cells or tumours results in their proliferation with an altered expression profile (Fox et al, 2001).

Somatostatin is a widely distributed inhibitory polypeptide that inhibits exocrine secretion, cellular proliferation and cellular differentiation, and promotes apoptosis. The effects of Somatostatin and its analogues are mediated via five G-protein-linked receptors (sst $1,2,3,4,5$ ). These receptors act through multiple signal transduction pathways to elicit their inhibitory effects.

Proliferating endothelium in vitro express sst 2 that is also expressed by endothelial cells within or adjacent to tumours (Reubi et al, 1994, 1996, 2001; ten Bokum et al, 1999, Watson et al, 2001; Koizumi et al, 2002), and it has been shown that sst 2 is expressed in the angiogenic sprouts of endothelium from placental veins (Watson et al, 2001). Experimental angiogenesis has been inhibited by the synthetic sst analogue Octreotide (Woltering et al,

*Correspondence: Dr SL Atkin, The Michael White Diabetes Centre, 220-236, Anlaby Road, Hull HU3 2RW, UK; E-mail: S.L.Atkin@hull.ac.uk Received 27 May 2004; revised 24 January 2005; accepted 8 February 2005; published online 5 April 2005
1991; Danesi and Del Tacca, 1996; Danesi et al, 1997) that has a high affinity for sst 2 . Human umbilical vein endothelial cells (HUVECs), which are widely used as an endothelial cell model in vitro, have also been shown to express sst 2 (Curtis et al, 2000).

Sst 1 has previously been detected in HUVECs (Curtis et al, 2000), and in the endothelium of neuroblastomas (Albers et al, 2000) and benign and malignant ovarian tumours (Hall et al, 2002). Sst 3 expression has also been demonstrated in HUVECs (Jia et al, 2003), and in the endothelial cell line Eahy926 (Florio et al, 2003). Sst 4 has only been reported in HUVECs (Curtis et al, 2000). There are currently no reports in the literature indicating that sst 1,3 or 4 expression is unique to proliferating vessels. The expression of sst 5 in primary human endothelial cells remains unreported.

Therefore, with the knowledge of the selective expression of sst 2 in proliferating endothelial cells, the aim of these studies was to determine whether there was a change in sst 1, 3, 4 and 5 expression in proliferating $v s$ quiescent human umbilical endothelial cells in vitro.

\section{MATERIALS AND METHODS}

\section{HUVEC isolation and culture}

Human umbilical cords were obtained from Hull Maternity Hospital with permission from the local ethics committee and 
informed patient consent. HUVECs were harvested by collagenase digestion, according to the method by Jaffe et al (1973). Reagents were purchased from Invitrogen (Paisley, UK), unless otherwise stated. Cells were routinely cultured in D-MEM with $5 \mathrm{~mm}$ D-glucose supplemented with $20 \%$ foetal bovine serum (FBS), $20 \mathrm{ng} \mathrm{ml}^{-1}$ human $\beta$-endothelial cell growth factor (Sigma, Poole, $\mathrm{UK}), 8 \mathrm{U} \mathrm{ml}^{-1}$ heparin sodium salt (Sigma), $2 \mathrm{~mm}$ L-glutamine, $50 \mathrm{U} \mathrm{ml}^{-1}$ penicillin $\mathrm{G}$ and $50 \mu \mathrm{g} \mathrm{ml}^{-1}$ streptomycin sulphate. Culture vessels were coated in $1 \%$ gelatin (Sigma) for $10 \mathrm{~min}$ prior to use. The HUVECs were grown at $37^{\circ} \mathrm{C}$ with $5 \% \mathrm{CO}_{2}$ in a humidified environment. Immunohistochemical detection of von Willebrand factor confirmed that the cells were of endothelial origin. Cells were passaged at a ratio of $1: 3$ after reaching $80-90 \%$ confluence, and media were replenished every $48 \mathrm{~h}$.

\section{Establishment of proliferating and quiescent HUVECs}

In all, 14 separate HUVECs lines derived from different patients were seeded into six-well plates at a density of $10^{5}$ cells well $^{-1}$ in $2 \mathrm{ml}$ of medium. Cells that approximately doubled in number within $24 \mathrm{~h}$, as determined by microscopic examination, were tentatively identified as proliferating cells. Quiescent cells were left to grow until confluent and then the medium was replaced with growth factor-free medium for $24 \mathrm{~h}$. Growth factor-free medium lacked ECGF and heparin sodium salt, and FBS was replaced with charcoal-stripped FBS. The viability of quiescent cells was demonstrated by passaging them at a $1: 2$ ratio after $48 \mathrm{~h}$ growth factor deprivation, and then confirming that they grew to confluence again within $48 \mathrm{~h}$. The proliferative status of the cells was confirmed using cell cycle analysis as described below. Nine of the lines of proliferating and quiescent HUVECs were grown in triplicate for RNA extraction. The three lines were used for cell cycle analysis alone, one line was used for the immunohistochemistry and another to determine the effects of the somatostatin analogues Octreotide and SOM230 on HUVEC proliferation.

\section{HUVEC cell cycle analysis}

Propidium-iodide-stained samples were analysed for cell cycle distribution as described previously (Newton et al, 2003). Briefly, HUVECs from six-well plates were centrifuged at $200 \mathrm{~g}$ for $10 \mathrm{~min}$, resuspended in $300 \mu \mathrm{l}$ phosphate-buffered saline (PBS) and then fixed in $70 \%$ ice-cold ethanol overnight. The cells were recovered by centrifugation, and resuspended in $250 \mu \mathrm{l}$ of PBS to which $10 \mu \mathrm{l}$ of $0.5 \mathrm{mg} \mathrm{ml}^{-1}$ propidium iodide solution was added. Following the addition of propidium iodide, the samples underwent incubation for $30 \mathrm{~min}$ at $37^{\circ} \mathrm{C}$. Samples were analysed with a FACS ${ }^{\text {CALIBUR }}$ flow cytometer (Becton Dickinson, Cowley, UK) with an argon laser tuned to $488 \mathrm{~nm}$. Forward and orthogonal light scatter and red fluorescence (FL-2) were then determined from at least 10000 events. Histogram plots were analysed using the cell cycle analysis software, Modfit (Becton Dickinson).

\section{Quantitative reverse transcriptase-real-time polymerase chain reaction ( $\mathrm{qRT}-\mathrm{PCR}$ )}

Primer sets were then submitted to a BLAST search at http:// www.ncbi.nlm.nih.gov/BLAST/ to confirm their uniqueness. The specificity of each primer set was confirmed in the results for the relative expression of sst in proliferating and quiescent HUVECs, where the detection of any one sst does not depend on the detection of another. RNA was extracted from HUVECs grown in six-well plates using Trizol (Invitrogen), as directed. Since sst are intronless, RNA from each sample was treated with deoxyribonuclease I (Invitrogen) to remove contaminating genomic DNA prior to reverse transcription, in the presence of RNAsin ribonuclease inhibitor (Promega UK Ltd, Southampton, UK). The RNA was reverse transcribed with Moloney murine leukaemia virus reverse transcriptase using random primers (Invitrogen), according to the manufacturer's instructions. qRT-PCR was performed utilising the ABI prism 5700 sequence detection system (Applied Biosystems, Warrington, UK). Sst 1-5 oligonucleotide forward primers, reverse primers and internal probes were designed using Primer Express version 1.0 (Applied Biosystems), and synthesised by MWG-Biotech (Ebersberg, Germany). The internal probes were labelled at the $5^{\prime}$-ends with the reporter fluorochrome 6carboxyfluorescein and at the $3^{\prime}$-ends with the quencher fluorochrome 6-carboxytetramethylrhodamine. These primers and probes are detailed in Table 1 . Each reaction volume was $25 \mu \mathrm{l}$, and contained $1 \times$ TaqMan Universal Master Mix (Applied Biosystems), $5 \mu \mathrm{l} \mathrm{cDNA}, 300 \mathrm{~nm}$ forward primer, $300 \mathrm{~nm}$ reverse primer and $150 \mathrm{~nm}$ internal probe. Amplification of the human $\beta$-glucoronidase housekeeping gene (Applied Biosystems) was used as an internal standard. Water was used as a nontemplate control. Nonreverse-transcribed samples were run in parallel to confirm that positive results were not due to amplification of genomic DNA. Human genomic DNA was used as a positive control for all sst. The PCR cycle consisted of an initial cycle of $50^{\circ} \mathrm{C}$ for $2 \mathrm{~min}$ followed by $95^{\circ} \mathrm{C}$ for $10 \mathrm{~min}$, and then 50 repeated cycles of $95^{\circ} \mathrm{C}$ for $15 \mathrm{~s}$ (denaturation) and $60^{\circ} \mathrm{C}$ for $1 \mathrm{~min}$ (primer annealing and

Table I Sst I, 2, 3, 4, 5 oligonucleotide forward primers, reverse primers and internal probes

\begin{tabular}{|c|c|c|}
\hline SSTR I & $\begin{array}{l}\text { Forward primer } \\
\text { Reverse primer } \\
\text { Probe }\end{array}$ & $\begin{array}{l}\text { 5'-GCTCGGAGCGCAAGATCA-3' } \\
\text { 5'-CGTCGTCCTGCTCAGCAAA-3' } \\
\text { 5'-CTTAATGGTGATGATGGTGGTGATGGTGTTT-3' }\end{array}$ \\
\hline SSTR 3 & $\begin{array}{l}\text { Forward primer } \\
\text { Reverse primer } \\
\text { Probe }\end{array}$ & $\begin{array}{l}\text { 5'-TGGGCCTGCTGGACTC-3' } \\
\text { 5'-GTTGAGGATGTAGACGTTGGTGACT-3' } \\
\text { 5'-CCGTGTGCCGCAGGACCACA-3' }\end{array}$ \\
\hline SSTR 4 & $\begin{array}{l}\text { Forward primer } \\
\text { Reverse primer } \\
\text { Probe }\end{array}$ & $\begin{array}{l}\text { 5'-GCGCTCGGAGAAGAAAATCA-3' } \\
\text { 5'-GGCTGGTCACGACGAGGTT-3' } \\
\text { 5'-CGTCTITGTGCTCTGCTGGATGCCTT-3' }\end{array}$ \\
\hline SSTR 5 & $\begin{array}{l}\text { Forward primer } \\
\text { Reverse primer } \\
\text { Probe }\end{array}$ & $\begin{array}{l}\text { 5'-TCATCCTCTCCTACGCCAACA-3' } \\
\text { 5'-TGGAAGCTCTGGCGGAAGT-3' } \\
\text { 5'-CCGTCCTCTCAGGCTTCCTCTCGGA-3' }\end{array}$ \\
\hline
\end{tabular}

Sst = somatostatin; SSTR $=$ somatostatin receptor 
extension). Proliferating and quiescent HUVECs that were to be compared were assayed simultaneously to ensure accurate relative quantification as described previously (Green et al, 2002).

\section{Immunohistochemistry}

Proliferating and quiescent cells were cultured as above in Labtec chamber slides in quadruplicate (Nunc, Wiesbaden, Germany). The media were removed and the cells were fixed in $95 \%$ ice-cold ethanol for $60 \mathrm{~min}$, followed by washing in PBS three times. Immunocytochemistry was performed for sst 2 and 5 as detailed previously (Stafford et al, 2004). Briefly, nonspecific binding sites were blocked with an Avidin/Biotin Blocking Kit (Vector Ltd, UK) and nonspecific serum protein block and endogenous peroxidase activity was quenched by incubating the cells with $1 \% \mathrm{H}_{2} \mathrm{O}_{2}$. Rabbit monoclonal antibodies to sst 2 and 5 were obtained from Gramsch Laboratories (Schwabhausen, Germany). Sections were then incubated overnight at $4{ }^{\circ} \mathrm{C}$ with primary antibody, diluted to $1: 10000$ in PBS plus $1 \%$ bovine serum albumin and $0.3 \%$ Triton $\mathrm{X}-100$.

Signal from the bound primary antibody was then amplified and visualised using the DAKO Catalysed Signal Amplification Peroxidase System K1500 (Dako, High Wycombe, Bucks, UK). The streptavidin/biotin complex was applied and signal amplified by adding the amplification reagent prior to streptavidin peroxidase. Immunoreactivity was then visualised by adding hydrogen peroxide as the enzyme substrate, in the presence of $0.05 \% 3,3^{\prime}$-diaminobenzidine. Signal was intensified with copper sulphate and nuclei lightly counterstained with Harris haematoxylin, before rehydrating and mounting with DPX.

Samples of anterior pituitary and normal pancreas known to express the relevant antigen were used as positive controls. Negative controls included omission of the primary antibody and incubation with $1 \%$ nonimmune serum.

\section{Effect of the somatostatin analogues Octreotide and SOM230}

To determine whether sst may be functionally important in proliferation, dose-response curves were constructed with the somatostatin analogues Octreotide and SOM230 (a gift from Novartis Ltd, Basle, Switzerland). Octreotide is a somatostatin analogue in clinical practice that has affinity for sst 2 and 5 $\left(0.38 \pm 0.08\right.$ and $6.3 \pm 1.0 \mathrm{IC}_{50}(\mathrm{~nm}) \pm$ s.e.m., respectively), while SOM230 is an experimental multiligand receptor analogue that has affinity for sst $1,2,3$ and $5(9.3 \pm 0.1,1.0 \pm 0.1,1.5 \pm 03$ and $0.16 \pm 0.01 \mathrm{IC}_{50}(\mathrm{nM}) \pm$ s.e.m., respectively). HUVEC proliferation was assessed using the WST-1 proliferation assay (Roche, Lewes, UK). HUVECs were aliquoted into gelatin-coated 96-well culture plates at a density of 2500 cells-well ${ }^{-1}$. After $18 \mathrm{~h}$ incubation, the medium was replaced with fresh medium containing $20 \%$ charcoal-stripped FBS, and excluding regular FBS and ECGF. At $6 \mathrm{~h}$ after the medium was switched, HUVECs were treated with $10^{-6}-10^{-10} \mathrm{M}$ SOM230 and Octreotide in parallel for $21 \mathrm{~h}$. For the final $3 \mathrm{~h}$ of incubation, WST-1 was added to each well according to the manufacturer's instructions, and absorbance measured hourly for $3 \mathrm{~h}$, at a wavelength of $450 \mathrm{~nm}$ with a reference wavelength of $620 \mathrm{~nm}$ using an Anthos 2010 plate reader (Anthos-Labtec, Salzburg, Austria). To ensure that sst 5 was expressed under these conditions, immunostaining for sst 5 was undertaken and shown to be positive. Six replicates were performed for each point of the dose-response curves.

\section{Statistical analysis}

The data were analysed with SPSS 11.5 (SPSS Science, Chicago, IL, USA). The proportion of HUVECs in each phase of the cell cycle was compared between proliferating and quiescent samples using
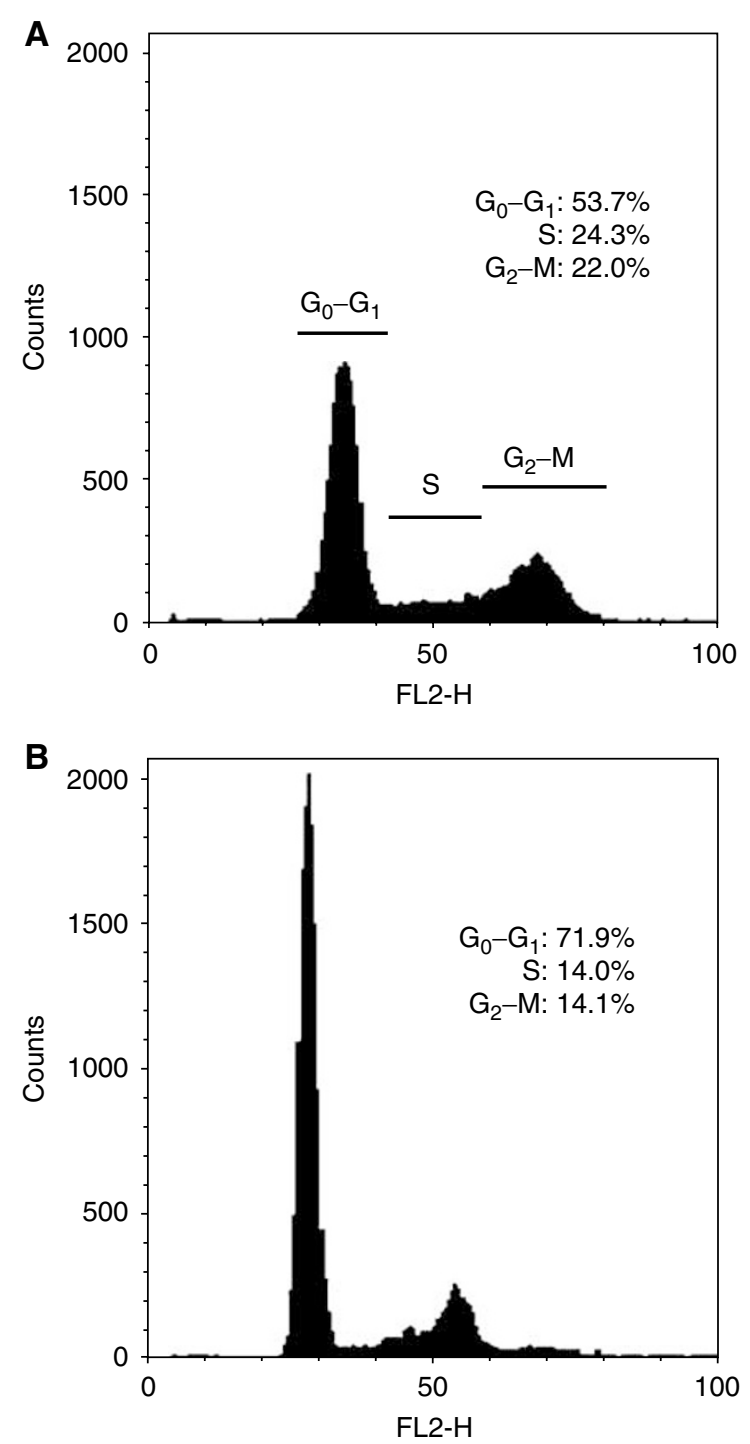

Figure I Flow cytometry for cell cycle parameters of propidium-iodidestained samples of $(\mathbf{A})$ proliferative, and (B) quiescent HUVECs. This was performed in triplicate for cells derived from each patient.

Table 2 Expression of sst 1,2 and 5 in proliferating and quiescent HUVECs, including relative expression of sst 2 and 5

\begin{tabular}{|c|c|c|c|c|c|c|c|c|}
\hline \multirow[b]{3}{*}{ Patient } & \multicolumn{8}{|c|}{ Receptor } \\
\hline & \multicolumn{2}{|c|}{ SSTR I } & \multicolumn{2}{|c|}{ SSTR 2} & \multicolumn{2}{|c|}{ SSTR 3} & \multicolumn{2}{|c|}{ SSTR 5} \\
\hline & $\mathbf{P}$ & $\mathbf{Q}$ & $\mathbf{P}$ & $\mathbf{Q}$ & $\mathbf{P}$ & $\mathbf{Q}$ & $\mathbf{P}$ & $\mathbf{Q}$ \\
\hline I & - & + & + & - & - & + & + & - \\
\hline 2 & + & + & + & - & - & - & + & - \\
\hline 3 & + & + & + & - & - & - & - & - \\
\hline 4 & + & + & + & - & - & - & - & - \\
\hline 5 & + & + & + & - & - & - & + & - \\
\hline 6 & + & - & - & - & - & - & - & - \\
\hline 7 & - & - & + & - & + & - & + & - \\
\hline 8 & - & + & - & - & - & - & + & - \\
\hline 9 & - & - & $100 \pm 43.0 \%$ & $12.2 \pm 8.5 \%$ & - & - & $100 \pm 10.7 \%$ & $1.1 \pm 1.4 \%$ \\
\hline
\end{tabular}


the unpaired $t$-test. The expression of sst was compared between proliferating and quiescent samples using the Mann-Whitney $U$-test. $P$-values $<0.05$ were considered statistically significant. Data from the WST-1 proliferation assay were analysed using ANOVA with post hoc Dunnett's pairwise multiple comparison $t$-tests. $P$-values $<0.05$ were considered statistically significant.

\section{RESULTS}

\section{Cell cycle analysis of proliferating and quiescent HUVECs}

Quiescent cells demonstrated reduced cell cycle progression in comparison to the corresponding proliferating cells (Figure 1). The proportion of quiescent cells in the $S$ phase of the cell cycle distribution was significantly lower than that of the corresponding proliferating cells (reduced by $18.1 \pm 5.8-43.8 \pm 2.4 \% ; P<0.05$; Figure 1). Additionally, significantly more quiescent endothelial cells were distributed in the $\mathrm{G}_{0}-\mathrm{G}_{1}$ phases (increased by $31.9 \pm 2.5-73.1 \pm 3.2 \% ; P<0.05 ;$ Figure 1$)$. This indicated that HUVECs subjected to $24 \mathrm{~h}$ growth factor deprivation were prevented from progressing from $\mathrm{G}_{0}-\mathrm{G}_{1}$ to $S$ phase. This validated our protocol for the establishment of proliferating and quiescent endothelial cell cultures.
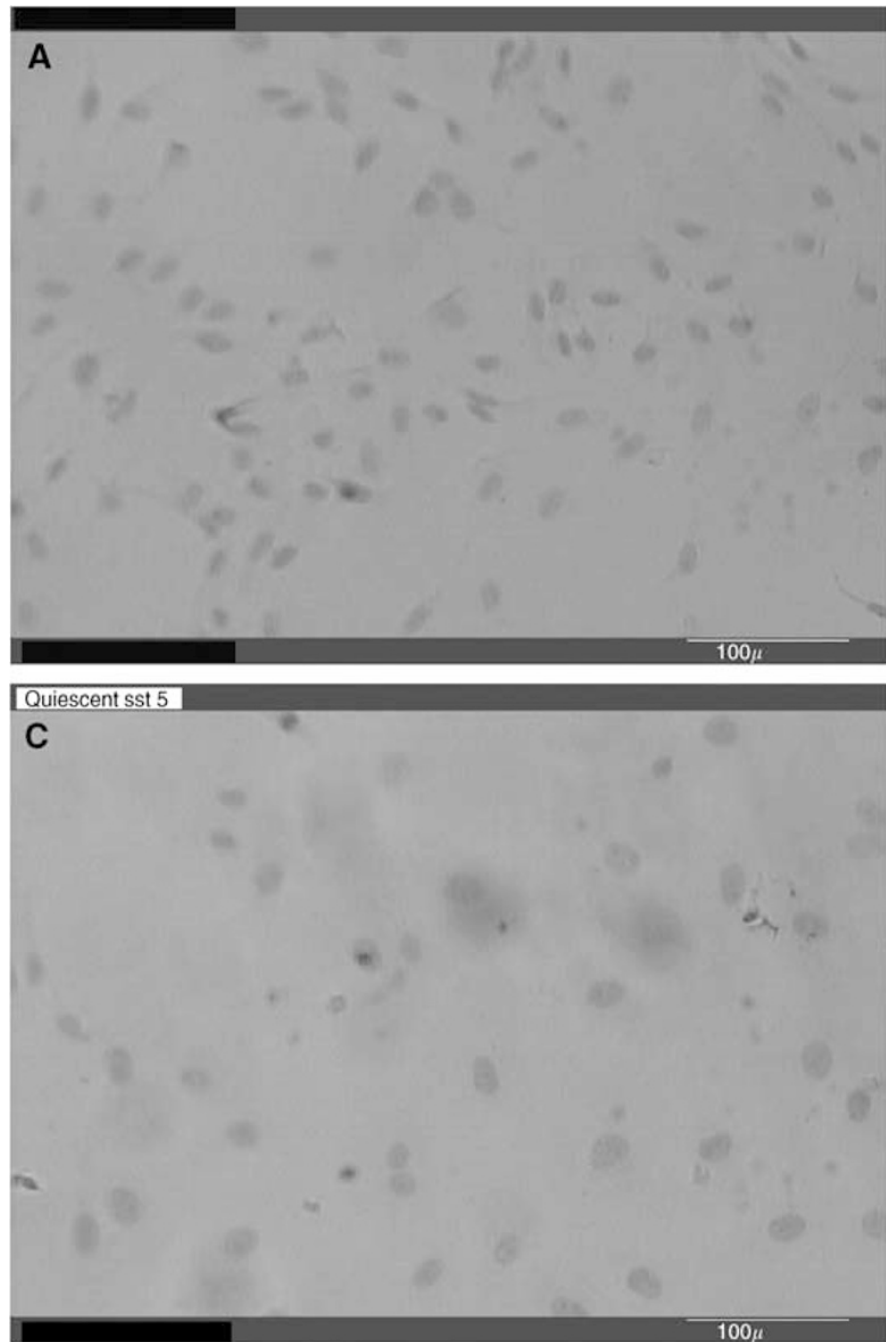

\section{qRT - PCR of proliferating and quiescent HUVECs}

Sst 2 and 5 were preferentially expressed in proliferating cultures (Table 2). There appeared to be no relationship between cell cycle progression and sst 1 or 3 expression (Table 2); therefore, these sst were not quantified. Only one of the quiescent cultures was positive for sst 2 , and the expression of sst 2 in this sample was significantly lower than that of the corresponding proliferating culture $(P<0.01)$. The quiescent culture from this sample was also positive for sst 5 , and again, the expression was significantly reduced $(P<0.01)$. Considering that all other quiescent samples were negative for sst 2 and 5 , it is possible that this sample contained proliferating cells. Most of the proliferating samples coexpressed at least two receptors, and sst 2 was always coexpressed with at least one other receptor. Sst 1 and 5 were only expressed simultaneously if sst 2 was also expressed. All samples were negative for sst 4 .

\section{Immunohistochemistry}

Sst 2 and 5 receptor positivity was seen in all proliferating but not quiescent HUVEC culture (Figure 2A and C, quiescent cells are negative for sst 2 and sst 5, respectively; Figure 2B and D, uniform immunopositivity for sst 2 and 5 in the proliferating cells).
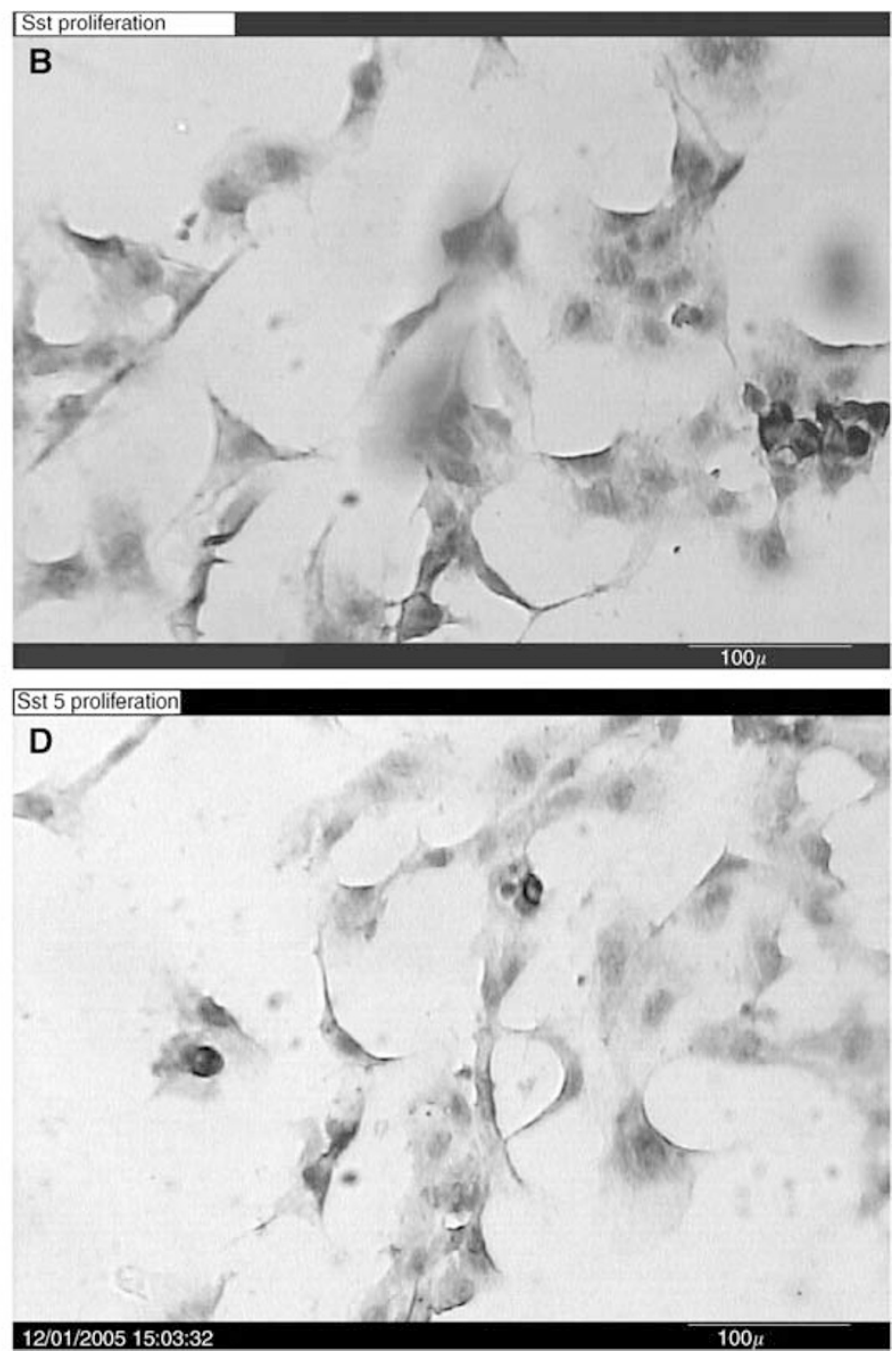

Figure 2 Immunohistochemistry: immunostaining was performed in cultures on chamber slides in quadruplicate. (A) Quiescent cells are negative for sst 2 positivity; (B) uniform immunopositivity for sst 2 in the proliferating cells; (C) quiescent cells are negative for sst 5 positivity; and (D) uniform immunopositivity for sst 5 in the proliferating cells (magnification $\times 10$ ). 


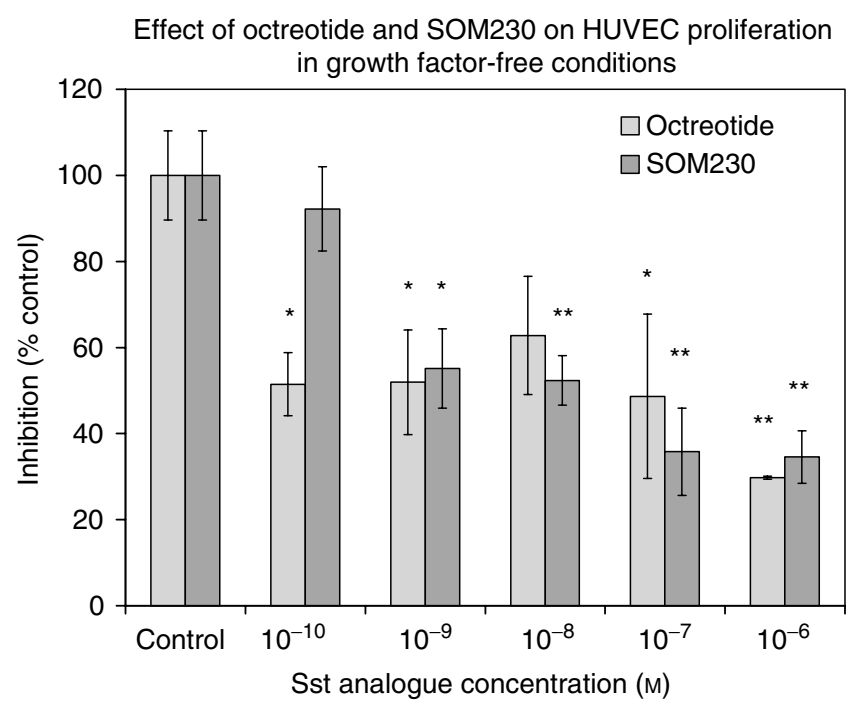

Figure 3 Effect of Octreotide and SOM230 on HUVEC proliferation in growth factor-free conditions. Octreotide significantly inhibited HUVEC proliferation across the concentration range $10^{-10}-10^{-6} \mathrm{M}(48.5 \pm 7.3-$ $70.2+0.4 \%$ inhibition), while SOM230 significantly inhibited HUVEC proliferation across the concentration range $10^{-9}-10^{-6} \mathrm{M}(44.9 \pm 9.2-$ $65.4+6.1 \%$ inhibition) in a dose-dependent manner. Effects on proliferation were determined using the WST-I proliferation assay. Data are expressed as mean \pm s.e.m., determined from six replicates. $* * P<0.01$, $* P<0.05$.

\section{Effect of Octreotide and SOM230 on HUVEC proliferation}

Octreotide significantly inhibited HUVEC proliferation across the concentration range $10^{-10}-10^{-6} \mathrm{M}(48.5 \pm 7.3-70.2 \pm 0.4 \%$ inhibition), while SOM230 significantly inhibited HUVEC proliferation across the concentration range $10^{-9}-10^{6} \mathrm{M}(44.9 \pm 9.2-65.4 \pm 6.1 \%$ inhibition) in a dose-dependent manner (Figure 3 ).

\section{DISCUSSION}

We have identified that sst 2 and 5 are preferentially expressed in the proliferating phenotype in HUVECs, and that a proportion of HUVECs express sst 1 and 3, irrespective of proliferative status. Our results support previous in vivo and in vitro findings on the preferential expression of sst 2 in activated endothelial cells (Reubi et al, 1994, 1996, 2001; ten Bokum et al, 1999; Koizumi et al, 2002). The finding that both sst $5 \mathrm{mRNA}$ and positive immunostaining for sst 5 were expressed in HUVECs, and altered with proliferative status, is novel and indicates that both the mRNA and the protein are expressed in proliferation. Sst 5 has not been specifically reported in vessels surrounding tissues with characteristic neovascularisation. In tumours, however, the presence of mRNA for sst 2, sst 5, or for both, has positively correlated with ${ }^{125} \mathrm{I}-$ $\left[\mathrm{Tyr}^{3}\right]$-Octreotide binding sites. In 1998, Siehler et al suggested that ${ }^{125} \mathrm{I}-\left[\mathrm{Tyr}^{3}\right]$-Octreotide binding is frequently attributable to sst 5. Considering that ${ }^{125} \mathrm{I}-\left[\mathrm{Tyr}^{3}\right]$-Octreotide has high affinity for sst 2 and moderate affinity for sst 5 , it is probable that Octreotide binding previously reported in peritumoral vessels may have been partially due to the presence of sst 5 , in accordance with our findings in HUVECs. Sst 5 is preferentially expressed in mitogenstimulated human T-lymphocytes (Ghamrawy et al, 1999), and we have now shown that this preferential expression extends to endothelial cells. Vapreotide (an analogue with sst 2 and 5 activity) has been shown to inhibit proliferation of CCK-stimulated $\mathrm{CHO}$ cells, which expressed endogenous CCK receptors and that were transfected with sst 5 . The effects of sst 5 appeared to be due to the inhibition of guanylate cyclase, and a consequent reduction in cyclic GMP formation, which modulated the activation of the MAPK cascade (Cordelier P et al, 1997). As MAP kinase activation is associated with proliferation of endothelial cells (Bogatcheva et al, 2003; Pintus G et al, 2003), its inhibition may potentially be the mechanism by which sst 5 activation may have an antiproliferative action.

The finding that HUVEC proliferation was inhibited by both Octreotide and SOM230 indicates the likelihood that sst 2 and 5 are functional in the proliferation of these endothelial cells. However, as both Octreotide and SOM230 have both sst 2 and 5 activities, it is unclear whether it is activation of either or both that is causing the inhibition of proliferation. The recent development of a new generation of somatostatin analogues that target different receptor combinations (Lamberts et al, 2002) will aid in further characterisation of the role of sst in the endothelium.

Despite much evidence of the antiproliferative effects of sst 2 activation, the clinical use of Octreotide as an antineoplastic agent has been disappointing (Hejna et al, 2002). This may in part be due to the presence of sst 5 on peritumoral vessels. Recently, Zatelli et al (2001) showed that sst 5 agonists can inhibit the antiproliferative activity of sst 2 agonists in the human medullary thyroid carcinoma cell line TT. Sst 2 and sst 5 exert antiproliferative effects in the pituitary cell line AtT-20 via similar mechanisms (Tallent et al, 1996), yet in CHO cells, the two receptors exert their antiproliferative effects via different mechanisms (Buscail et al, 1995). This suggests that the effects of coactivation of sst 2 and 5 are highly tissue specific, and perhaps the antiproliferative effects of sst 2 are antagonised by sst 5 in the endothelium.

We have also shown that HUVECs express sst 1 irrespective of proliferative status. The expression of sst 1 in both proliferating and quiescent endothelium, however, does not eliminate sst 1 as a suitable therapeutic target. In CHO-K1 cells, sst 1 induces cytostatic effects by modulating the MAP kinase pathway (Florio et al, 2000). Also, Buchan et al (2002) have shown that activation of sst 1 inhibits endothelial cell migration. There has been no evidence to date, however, that sst 1 induces apoptosis. The activation of endothelial sst 1 may therefore inhibit cell migration and induce cytostatic effects in proliferating endothelial cells, without inducing apoptosis in quiescent cells. The expression of sst 1 in quiescent cells also suggests that sst 1 may have other roles in endothelial functions that are not associated with cell cycle progression.

Our results also show that HUVECs express sst 3, in accordance with the findings of Jia et al (2003). Only two of our samples, however, expressed this receptor subtype. Florio et al (2003) found that sst inhibits DNA synthesis in the sst 3-expressing endothelial cell line Eahy926, and that this effect was blocked by a sst 3 subtype-specific antagonist.

We observed high variability in the coexpression of sst by proliferating HUVECs.

Coexpression of sst 2 and 5 occurred in five of nine proliferating samples. Also, two of nine proliferating samples expressed sst 2 when sst 5 was absent, and one of nine expressed sst 5 when sst 2 was absent. It is possible that there is variation in the temporal expression of sst in HUVECs derived from different sources, and that coexpression of sst 2 and 5 may transiently occur in more samples than is indicated in this study. The cause of this variability is unclear; a similar phenomenon occurs in the immunocytohistochemical detection of sst in tumour vessels from different patients (Reubi et al, 1994). Inconsistencies in sst expression are not unique to the endothelium, and variation is evident in a wide range of normal and neoplastic tissues (Hofland and Lamberts, 2001; Reubi et al, 2001). This high variability in the coexpression of endothelial sst may be of particular importance in the clinical application of sst analogue therapy. 
Overall, these data show that sst may have a functional role in angiogenesis with dynamic changes in sst 2 and 5 expression during proliferation and inhibition of proliferation by the analogues that have sst 2 and 5 activity. Further characterisation of the role of endogenous sst and its receptors in modulating endothelial function in other endothelial cell models may define their role further.

\section{REFERENCES}

Albers AR, O'Dorisio MS, Balster DA, Caprara M, Gosh P, Chen F, Hoeger C, Rivier J, Wenger GD, O'Dorisio TM, Qualman SJ (2000) Somatostatin receptor gene expression in neuroblastoma. Regul Peptides 88: 61-73

Bogatcheva NV, Dudek SM, Garcia JG, Verin AD (2003) Mitogen-activated protein kinases in endothelial pathophysiology. J Invest Med 51(6): $341-352$

Buchan AM, Lin CY, Choi J, Barber DL (2002) Somatostatin, acting at receptor subtype 1 , inhibits Rho activity, the assembly of actin stress fibers, and cell migration. J Biol Chem 277: 28431-28438

Buscail L, Esteve JP, Saint-Laurent N, Bertrand V, Reisine T, O'Carroll AM, Bell GI, Schally AV, Vaysse N, Susini C (1995) Inhibition of cell proliferation by the somatostatin analogue RC-160 is mediated by somatostatin receptor subtypes sst2 and sst5 through different mechanisms. Proc Natl Acad Sci USA 92: $1580-1584$

Cordelier P, Esteve JP, Bousquet C, Delesque N, O'Carroll AM, Schally AV, Vaysse N, Susini C, Buscail L (1997) Characterization of the antiproliferative signal mediated by the somatostatin receptor subtypes sst5. Proc Natl Acad Sci USA 94: 9343-9348

Curtis SB, Hewitt J, Yakubovitz S, Anzarut A, Hsiang YN, Buchan AM (2000) Somatostatin receptor subtype expression and function in human vascular tissue. Am J Physiol Heart Circ Physiol 278: H1815-H1822

Danesi R, Agen C, Benelli U, Paolo AD, Nardini D, Bocci G, Basolo F, Campagni A, Tacca MD (1997) Inhibition of experimental angiogenesis by the somatostatin analogue octreotide acetate (SMS 201-995). Clin Cancer Res 3: 265-272

Danesi R, Del Tacca M (1996) The effects of the somatostatin analog octreotide on angiogenesis in vitro. Metabolism 45: 49-50

Florio T, Morini M, Villa V, Arena S, Corsaro A, Thellung S, Culler MD, Pfeffer U, Noonan DM, Schettini G, Albini A (2003) Somatostatin inhibits tumor angiogenesis and growth via somatostatin receptor-3-mediated regulation of endothelial nitric oxide synthase and mitogen-activated protein kinase activities. Endocrinology 144: 1574-1584

Florio T, Thellung S, Arena S, Corsaro A, Bajetto A, Schettini G, Stork PJS (2000) Somatostatin receptor 1 (sst1)-mediated inhibition of cell proliferation correlates with the activation of the MAP kinase cascade: role of the phosphotyrosine phosphatase SHP-2. J Physiol Paris 94: $239-250$

Fox SB, Gasparini G, Harris AL (2001) Angiogenesis: pathological, prognostic, and growth-factor pathways and their link to trial design and anticancer drugs. Lancet Oncol 2: 278-289

Ghamrawy CE, Rabourdin-Combe C, Krantic S (1999) sst5 somatostatin receptor mRNA induction by mitogenic activation of human T-lymphocytes. Peptides 20: 305-311

Green VL, Richmond I, Maguiness S, Robinson J, Helboe L, Adams IP, Drummond NS, Atkin SL (2002) Somatostatin receptor 2 expression in the human endometrium through the menstrual cycle. Clin Endocrinol (Oxf) 56: 609-614

Griffioen AW, Molema G (2000) Angiogenesis: potentials for pharmacologic intervention in the treatment of cancer, cardiovascular diseases, and chronic inflammation. Pharmacol Rev 52: 237-268

Hall GH, Turnbull LW, Richmond I, Helboe L, Atkin SL (2002) Localisation of somatostatin and somatostatin receptors in benign and malignant ovarian tumours. Br J Cancer 87: 86-90

Hejna M, Schmidinger M, Raderer M (2002) The clinical role of somatostatin analogues as antineoplastic agents: much ado about nothing? Ann Oncol 13: 653-668

Hofland LJ, Lamberts SW (2001) Somatostatin receptor subtype expression in human tumors. Ann Oncol 12(Suppl 2): S31-S36
Jaffe EA, Nachman RL, Becker CG, Minick CR (1973) Culture of human endothelial cells derived from umbilical veins. Identification by morphologic and immunologic criteria. J Clin Invest 52: $2745-2756$

Jia WD, Xu GL, Xu RN, Sun HC, Wang L, Yu JH, Wang J, Li JS, Zhai ZM, Xue Q (2003) Octreotide acts as an antitumor angiogenesis compound and suppresses tumor growth in nude mice bearing human hepatocellular carcinoma xenografts. J Cancer Res Clin Oncol 129: 327 - 334

Koizumi M, Onda M, Tanaka N, Seya T, Yamada T, Takahashi Y (2002) Antiangiogenic effect of octreotide inhibits the growth of human rectal neuroendocrine carcinoma. Digestion 65: 200-206

Lamberts SW, van der Lely AJ, Hofland LJ (2002) New somatostatin analogs: will they fulfil old promises? Eur J Endocrinol 146: 701-705

Newton CJ, Xie Y, Burgoyne CH, Adams I, Atkin SL, Abidia A, McCollum PT (2003) Fluvastatin induces apoptosis of vascular endothelial cells: blockade by glucocorticoids. Cardiovasc Surg 11: $52-60$

Pintus G, Tadolini B, Posadino AM, Sanna B, Debidda M, Carru C, Deiana L, Ventura C (2003) PKC/Raf/MEK/ERK signaling pathway modulates native-LDL-induced E2F-1 gene expression and endothelial cell proliferation. Cardiovasc Res 59(4): 934-944

Reubi JC, Horisberger U, Laissue J (1994) High density of somatostatin receptors in veins surrounding human cancer tissue: role in tumor-host interaction? Int J Cancer 56: 681-688

Reubi JC, Schaer JC, Laissue JA, Waser B (1996) Somatostatin receptors and their subtypes in human tumors and in peritumoral vessels. Metabolism 45: $39-41$

Reubi JC, Waser B, Schaer JC, Laissue JA (2001) Somatostatin receptor sst1sst5 expression in normal and neoplastic human tissues using receptor autoradiography with subtype-selective ligands. Eur J Nucl Med 28: 836 846

Siehler S, Seuwen K, Hoyer D (1998) ${ }^{125} \mathrm{I}[\mathrm{Tyr} 3]$ octreotide labels human somatostatin sst2 and sst5 receptors. Eur J Pharmacol 348: $311-320$

Stafford ND, Condon LT, Rogers MJC, Macdonald AW, Atkin SL (2004) The expression of somatostatin receptors $1,2,3$ and 5 in acoustic neuromas. J Clin Pathol 57: 168 - 171

Tallent M, Liapakis G, O'Carroll AM, Lolait SJ, Dichter M, Reisine T (1996) Somatostatin receptor subtypes sst 2 and sst 5 couple negatively to an Ltype $\mathrm{Ca}^{2+}$ current in the pituitary cell line AtT-20. Neuroscience 71: $1073-1081$

ten Bokum AM, Melief MJ, Schonbrunn A, van der Ham F, Lindeman J, Hofland LJ, Lamberts SW, van Hagen PM (1999) Immunohistochemical localization of somatostatin receptor sst2A in human rheumatoid synovium. J Rheumatol 26: $532-535$

Watson JC, Balster DA, Gebhardt BM, O’Dorisio TM, O’Dorisio MS, Espenan GD, Drouant GJ, Woltering EA (2001) Growing vascular endothelial cells express somatostatin subtype 2 receptors. $\mathrm{Br} J$ Cancer 85: $266-272$

Woltering EA, Barrie R, O'Dorisio TM, Arce D, Ure T, Cramer A, Holmes D, Robertson J, Fassler J (1991) Somatostatin analogues inhibit angiogenesis in the chick chorioallantoic membrane. J Surg Res 50: $245-251$

Woltering EA, Watson JC, Alperin-Lea RC, Sharma C, Keenan E, Kurozawa D, Barrie R (1997) Somatostatin analogs: angiogenesis inhibitors with novel mechanisms of action. Invest New Drugs 15: 77-86

Zatelli MC, Tagliati F, Taylor JE, Rossi R, Culler MD, degli Uberti EC (2001) Somatostatin receptor subtypes 2 and 5 differentially affect proliferation in vitro of the human medullary thyroid carcinoma cell line tt. J Clin Endocrinol Metab 86: $2161-2169$ 